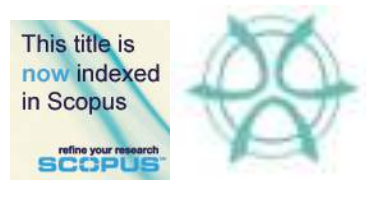

PLANNING MALAYSIA:

Journal of the Malaysian Institute of Planners

SPECIAL ISSUE IV (2016), Page 225 - 242

\title{
SPATIOTEMPORAL LAND USE AND LAND COVER CHANGE IN MAJOR RIVER BASINS IN COMPREHENSIVE DEVELOPMENT AREA
}

\author{
Wan Yusryzal Wan Ibrahim ${ }^{1} \&$ Ahmad Nazri Muhamad Ludin ${ }^{2}$ \\ 1,2 Faculty of Built Environment \\ UNIVERSITI TEKNOLOGI MALAYSIA
}

\begin{abstract}
Urbanization has significantly transformed spatial configuration of landscape structure which is triggered by population growth and government's development policy. As a consequence, the changes disturbed the quality of natural environment and ecosystem. Historical experience and prediction of future land use and land cover change is important to understand the spatial characteristics and environmental consequences of development area. Evaluating the spatiotemporal in urban development is essential as an important component improving adaptive management in landscape planning. Thus, the objective of this paper is to discuss the spatiotemporal land use and land cover change in major river basins (Sungai Tebrau, Sungai Skudai, Sungai Pulai and Coastal Zone) in the rapid development region of Iskandar Malaysia. The past experience indicates rapid growth of population and substantial urban development changed the spatial structure of the region and there is tremendous transformation of land use and land cover in the present due to high demand for development. Analytical Hierarchical Process (AHP) and CA-markov chain model were used to analyze the relationship of variables and formulate the future spatial changes. Then landscape index is used to analyze the spatial characteristics of the changes. Remote sensing data and GIS were used to conduct the analysis for the study. Temporal satellite images between 2002 and 2013 were utilized as input data for the past changes and basis for future land use and land cover change projection (2020, 2025 and 2025). The result indicates different character of urban landscape changes in different periods and river basins. Past experience shows the significant change of agricultural and natural land converted into artificial land use especially in Skudai and Tebrau river basins. In addition, there was conversion of water body for development in the past especially along the river banks and coastal area in Johor Bahru city center. This trend will constantly restructure the existing landscape as projection shows the significant impact of future development. This situation could contribute to other possible issues such as microclimate change and increase run-off water, pollution and degradation of ecological values and services. This study provides a platform for decision-makers to interpret the situation of landscape structure change in relation with environmental consequence in the study area. Future development plan should thoroughly consider the character of future spatial development and anticipate the possible effect on the environment in the region.
\end{abstract}

Keyword: LULC; GIS; spatiotemporal; river basin; landscape index 
Wan Yusryzal Wan Ibrahim \& Ahmad Nazri Muhamad Ludin

Spatiotemporal Land Use And Land Cover Change In Major River Basins In Comprehensive Development Area

\section{INTRODUCTION}

In the past decades, rapid land use and land cover changed due to high demand for urban land uses such as residential, commercial, industrial, infrastructure and utilities especially in developing countries. High population growth and evident policy evolution increased demand for more spaces that resulted in rapid urbanization. In relation to this, it is estimated that global urban population will be 3.8 billion in 2015 and expected to achieve 5 billion people in 2030 (Unesco, 2010). Thus, urban development will continue modifying the landscape structure globally. More artificial land uses will replace other landscapes and consequently disturbing environmental quality. In particular, the increasing artificial surfaces from various types of development areas could be the potential source of pollution within watershed area (Tanga et al., 2005; Xiana et al., 2007; Edwin et al., 2010 and Mark et al., 2011). Many past studies show significant impact of land use and land cover (LULC) change contributing to source for pollution and removing the existing landscape and increase exposure to other problems (Carlson et al,. 2011; Youa et al., 2012; Wang et al. 2012; Chu et al., 2013 and Fu et al., 2014). This will be more critical as future development will restructure the landscape and could contribute to negative issues in the environment.

Spatiotemporal study is important to understand the possible characteristics of spatial changes in past and future landscape. The dynamic change information is essential for experts to predict the possible impact of the changes towards environment (Lathrop et al., 2007; Sun et al., 2012 and Xu et al., 2013). In undertaking the study, GIS and remote sensing are important tools in analyzing the spatiotemporal of LULC change. Remote sensing provides a series of spatial features information with spatial pattern dimension and temporal changes (Frondoni et al., 2011; Wang et al., 2012). It illustrates the composition and configuration on the earth surface which relates to the land use activities. Meanwhile GIS is capable to handle spatial data and conduct analysis for the spatiotemporal study. Spatial analysis in GIS particularly is able to visualize the spatial dimension for the future development. Then, the analysis is enhanced when landscape indices specifically describes the composition and configuration spatiotemporal of land use and land cover change (Fan and Myint, 2014).

For further understanding of urbanization and spatiotemporal changes, the study was conducted in the comprehensive development region of Iskandar Malaysia (Johor Bahru). Previously, Johor Bahru especially has experienced significant change of LULC characteristics in recent years. Due to the implementation of new policy, presently there is no sign of slowing down the development. The rapid changes are related to the fast population growth in this area in line with the evolution of the policy to elevate Johor Bahru as a city of international standing (Figure 1). Thus, large areas have been converted into urban land use and the trend will continue as population and demand for spaces increase in the future.

Iskandar Malaysia region is now a comprehensive development region that covers 221634.1 hectares (2 216.3 square $\mathrm{km}$ ) of land area at the most southern part of Johor consisting the whole of Johor Bahru district and some areas in Pontian district. Previously, the study area was rich with ecological components such mangrove areas, swampland along the coast and rivers. Agriculture was also the dominant land use covering almost $70 \%$ of this area. Within the large agriculture land, natural forest areas were scattered with different configuration and compositions especially along the coastal zone. In 
economic activities, Johor Bahru particlularly is an important region that experienced large economic concentration and various spatial changes since 1990s. Now it has become one of the prominent cities in Malaysia having high competitive development especially for commercial, industrial and residential sectors. Population has grown considerably with enormous immigration of people from surrounding areas. As a result, large land use and land cover has significantly changed due to this rapid socioeconomic development and change the overall landscape. For the purpose of the study, the focus study area is in the major river basins within the region such as Sungai Pulai, Sungai Skudai, Sungai Tebrau and the coastal area around the city center of Johor Bahru (Figure 2).

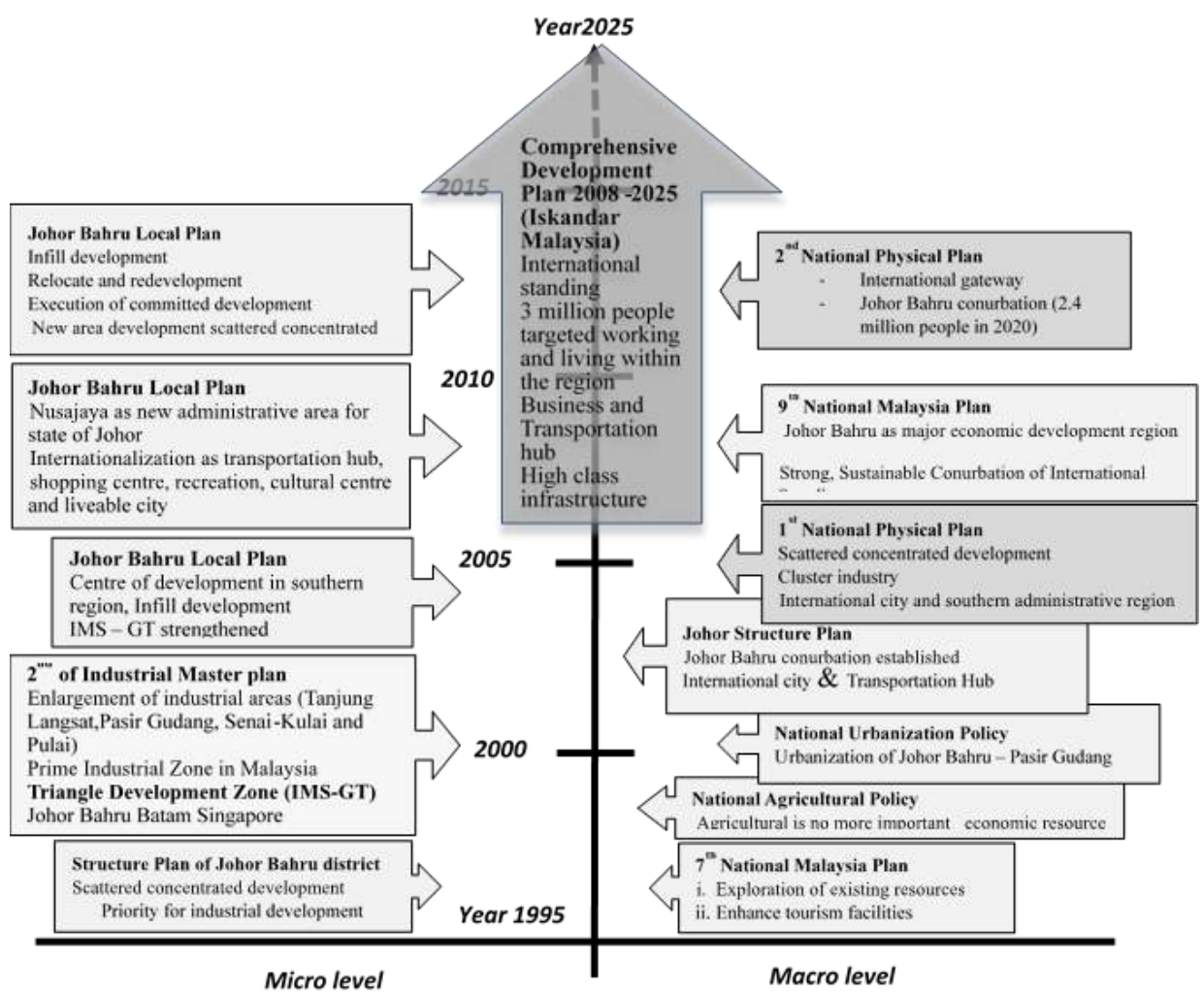

Figure 1: Temporal policy dimension changes in Johor Bahru 


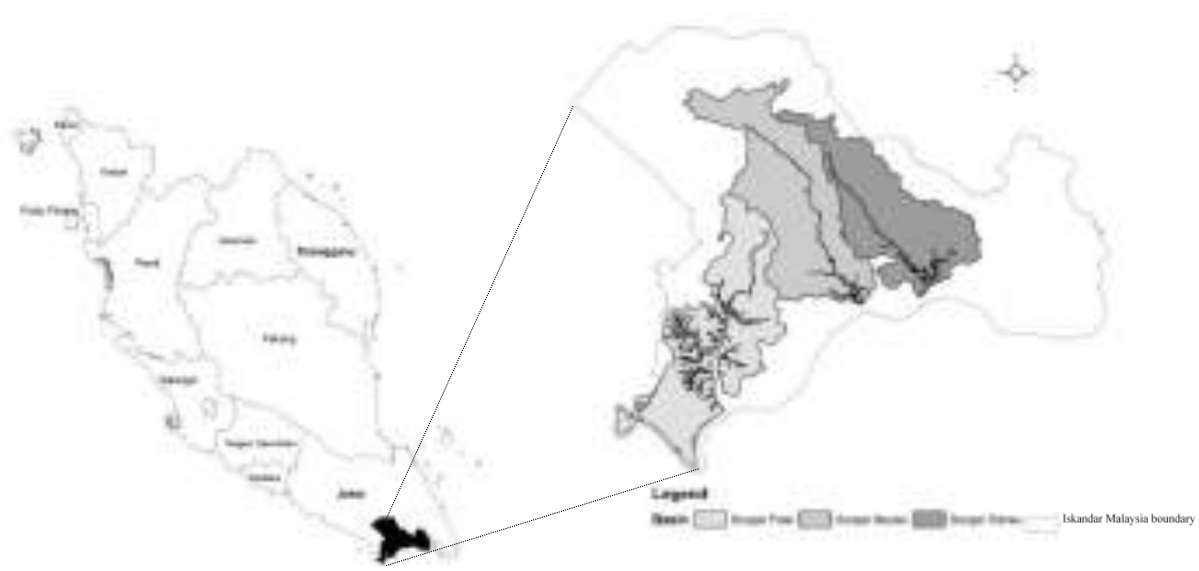

Figure 2: The river basins (study area) in Iskandar Malaysia region

\section{OBJECTIVE AND METHODS}

The objective of this paper is to discuss the spatiotemporal land use and land cover change in the three major river basins in Iskandar Malaysia region. It is important to understand the characteristics of land use and land cover of the study area related to the quality of river basin in this area. Besides that, this study references the requirement of adaptive management for observing and predicting the consequence of environmental problems. Several steps were involved in this study such as identification of the focus and study area, data collection, database development, image processing and data analysis (Figure $3)$.

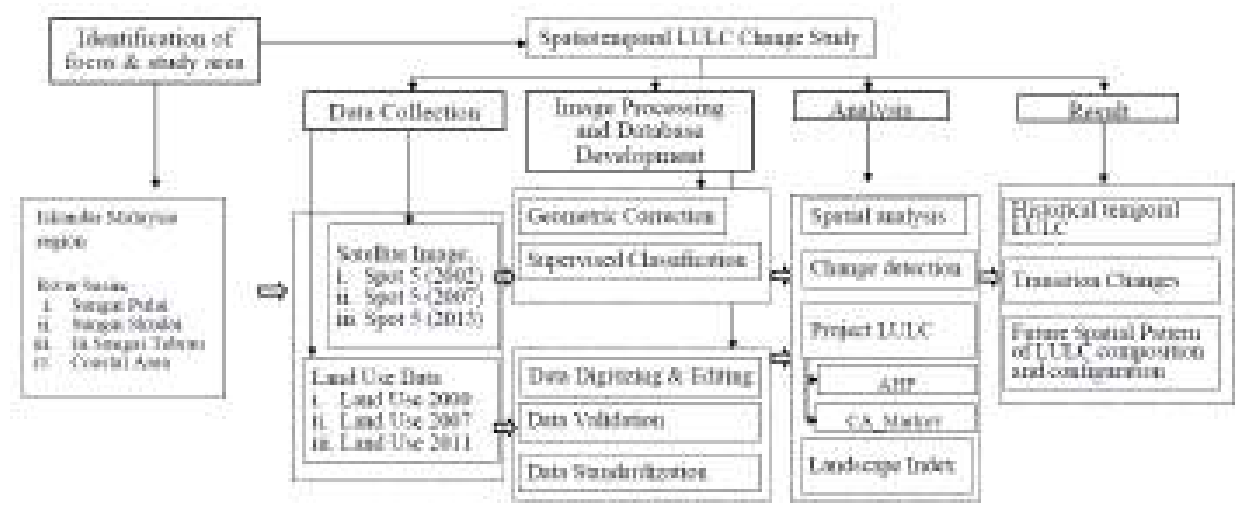

Figure 3: The sequence and methods involved in this study

\section{Data Collection and Database Development}

This temporal study focused on the historical experience and future spatiotemporal LULC change from 2015 to 2030 with regard to significant policy evolution. The past experiences were used as a basis for projecting the land use and land cover in the region. Series of temporal data was collected which includes a series of satellite images (2002, 
2007 and 2013) and other land use information. The Spot 5 satellite images with 10x10 meter accuracy were obtained from ARSM (Agencies of Remote Sensing Malaysia). The images are registered into Rectified Skewed Orthomorphic of Malaysia (RSO) coordinate system. Then by using supervised classification method the images were classified into five categories such as natural, agriculture, water body, built up and open land. Meanwhile, the land use data was collected from several sources in different formats. Past land use data was developed by referring to the printed documents. Land use in 2000 was digitized by referring to the past Local Plan of Johor Bahru and Structure Plan of Johor Bahru. Land use data in were 2007 and 2011 collected from secondary sources and then were transformed into standard format.

\section{Method of Analysis}

There are three sections of analysis in this study which is firstly to identify the historical character of change and secondly, to project the future spatiotemporal lulc change in the study area. Then, the landscape index analyzes the composition and configuration of the spatiotemporal changes in the past and future changes. The analysis reveals different characteristics of spatial pattern in the river basins. In the first part of analysis, the spatial analysis performs the transition of change analysis and indicates the location and type of the past changes. Similarly, the same method is used in analyzing the future change besides interpreting the configuration and composition of the change. Comparison of the LULC changes and trends from 2015 to 2030 is measured to reveal the behavior of the changes and impact on the river basins. Several software were used in this study such as Erdas Imagine, Idrisi Selva, ArcGIS and Fragstats to run the analysis.

In the second part of analysis, the projection of the LULC is based on the period from 2007 to 2013. This period is chosen because of apparent transformation with the current situation as well as in line with the starting point of the comprehensive development policy. Meanwhile the transition probability for urban changes is calculated based on a series of variables within the components of existing urban areas, transportation network, geophysical condition and development policy engagement. The map was created through input from analytical hierarchical process (AHP) which shows the priority area for future development.

The final part of analysis is analyzing the composition and configuration of LULC in the river basins from 2002 to 2030. This analysis is important to reveal spatial pattern of development and remaining natural areas in those river basins within the periods. Several matrices were selected at patch and landscape levels with regard to the required information to reveal the spatial composition and configuration of lulc change (Table 1). Those matrices were translated in spatial statistics package in Fragstats software developed by MacGarigal in 2002. In this stage, raster data format is used to calculate the spatial pattern characteristics of the LULC in the study area. Then, statistical table from the calculation was translated into graphs for better understanding of the LULC characteristics in the study area. 
Wan Yusryzal Wan Ibrahim \& Ahmad Nazri Muhamad Ludin

Spatiotemporal Land Use And Land Cover Change In Major River Basins In Comprehensive Development Area

Table 1: Selected landscape matrices to measure LULC characteristics of the study area

\begin{tabular}{|c|c|c|c|}
\hline Matrices & Abbreviation & Description & Unit \\
\hline $\begin{array}{l}\text { Percentage } \\
\text { landscape }\end{array}$ & PLAND & $\begin{array}{l}\text { Total percentage of land use } \\
\text { type compare to whole } \\
\text { landscape. }\end{array}$ & Percentage \\
\hline Number of patches & NP & $\begin{array}{l}\text { Total number of patches in } \\
\text { the landscape. }\end{array}$ & None \\
\hline Mean patch size & MPS & $\begin{array}{l}\text { The mean patch index } \\
\text { quantifies based on the } \\
\text { accumulation of patches in } \\
\text { the same type. }\end{array}$ & Percentage \\
\hline $\begin{array}{l}\text { Shahnon's diversity } \\
\text { index }\end{array}$ & SHDI & $\begin{array}{l}\text { Equal minus the sum, across } \\
\text { all patch type, of the } \\
\text { proportional abundance of } \\
\text { each patch type multiplied by } \\
\text { that proportion. }\end{array}$ & None \\
\hline $\begin{array}{l}\text { Shahnon's evenness } \\
\text { index }\end{array}$ & SHEI & $\begin{array}{l}\text { A measurement of patch } \\
\text { diversity, which is } \\
\text { determined by the } \\
\text { distribution of different types } \\
\text { of patch in landscape. }\end{array}$ & None \\
\hline
\end{tabular}

Source: Adopted from McGarigal, 2002

\section{URBANIZATION AND LANDSCAPE CHARACTER CHANGES}

\section{LULC Change}

The primary findings show that there was significant change of the land use and land cover in the past in the study area. It is obvious different trends of land use changes can be seen in the different periods of the study due to evolvement of urban development. The urban area has replaced the surrounding natural and agriculture areas and directly changed the overall landscape composition of the river basin in the study area (Figure 4 and Table 2). The total urban land of 22387.65 hectares in 2002 increased to 22441.31 hectare in 2007. In 2007 rapid urban development started due to the implementation of the comprehensive development plan in Iskandar Malaysia and shows that the urban land enlarged enormously. As a result, the total urban land increased to 645954.7 hectares in 2013. The changes significantly change the composition of every river basin in this region (Table 2).

In relation to the policy evolution, built up area was significantly increased from 2007 to 2013 due to the expansion of Johor Bahru city center. Thus, the most rapid changes of the landscape pattern are in the Tebrau river basin where urban land has increased significantly. There were lots of green vacant land and agriculture areas that have been converted through infill development and edge expansion. The trend is in line with the policy that focussed on the scattered concentrated and infill development. In addition, overspill of urban sprawl from Johor Bahru city centre has contributed to new development in the surrounding areas. There was significant change of urban land development in other river basins between 2007 and 2013 especially in the coastal zone and Skudai river basin. 
Table 2: The percentage of land cover in all the river basins in 2002, 2007 and 2013

\begin{tabular}{lccccccccccccc}
\hline $\begin{array}{l}\text { River } \\
\text { Basin }\end{array}$ & \multicolumn{3}{c}{ Coastal Zone } & \multicolumn{4}{c}{ Sungai Skudai } & \multicolumn{3}{c}{ Sungai Tebrau } & \multicolumn{3}{c}{ Sungai Pulai } \\
\hline $\begin{array}{l}\text { Land } \\
\text { Cover }\end{array}$ & $\mathbf{2 0 0 2}$ & $\mathbf{2 0 0 7}$ & $\mathbf{2 0 1 3}$ & $\mathbf{2 0 0 2}$ & $\mathbf{2 0 0 7}$ & $\mathbf{2 0 1 3}$ & $\mathbf{2 0 0 2}$ & $\mathbf{2 0 0 7}$ & $\mathbf{2 0 1 3}$ & $\mathbf{2 0 0 2}$ & $\mathbf{2 0 0 7}$ & $\mathbf{2 0 1 3}$ \\
\hline Bare Soil & 9.11 & 4.60 & 13.03 & 15.16 & 6.26 & 13.91 & 11.51 & 7.81 & 18.07 & 6.33 & 5.70 & 11.88 \\
$\begin{array}{l}\text { Built Up } \\
\text { Green/ }\end{array}$ & 14.00 & 23.52 & 29.87 & 24.72 & 27.20 & 32.74 & 30.82 & 29.00 & 34.94 & 7.21 & 9.56 & 15.26 \\
Agriculture & 38.25 & 40.18 & 30.64 & 47.36 & 50.41 & 43.66 & 47.04 & 53.05 & 38.46 & 37.9 & 41.12 & 32.33 \\
$\begin{array}{l}\text { Forest } \\
\text { Water }\end{array}$ & 26.44 & 19.65 & 15.42 & 11.33 & 14.92 & 8.41 & 9.45 & 9.02 & 7.53 & 37.11 & 33.76 & 31.64 \\
Body & 12.20 & 12.05 & 11.04 & 1.43 & 1.21 & 1.28 & 1.18 & 1.12 & 1.00 & 11.45 & 9.86 & 8.89 \\
\hline & 100 & 100 & 100 & 100 & 100 & 100 & 100 & 100 & 100 & 100 & 100 & 100 \\
\hline
\end{tabular}

Urban land enlargement in the study area is analyzed to characterize the urban land use transition. In the first period (2002-2007), agriculture land was the largest converted area to urban land with 8466.2212 hectares covering $68.87 \%$ from the total conversion (Figure 5 and Table 3). Meanwhile, the Tebrau river basin was the biggest area transformed in the first period and agriculture land was the major area converted into urban land with 2890.85 hectares. It shows that the urban sprawl of Johor Bahru city center was spread out a different magnitude being more concentrated towards Pasir Gudang region. This pattern is due to the policy that allocates this area as the main industrial area in Johor Bahru and agriculture as less important of economic activities in this region. Moreover, the enlargement of the industrial area is in regard to the policy to strengthen up industrial activities which subsequently increased the urban land footprint in the following periods (2007-2013) in the Tebrau river basin. 
Wan Yusryzal Wan Ibrahim \& Ahmad Nazri Muhamad Ludin

Spatiotemporal Land Use And Land Cover Change In Major River Basins In Comprehensive Development Area

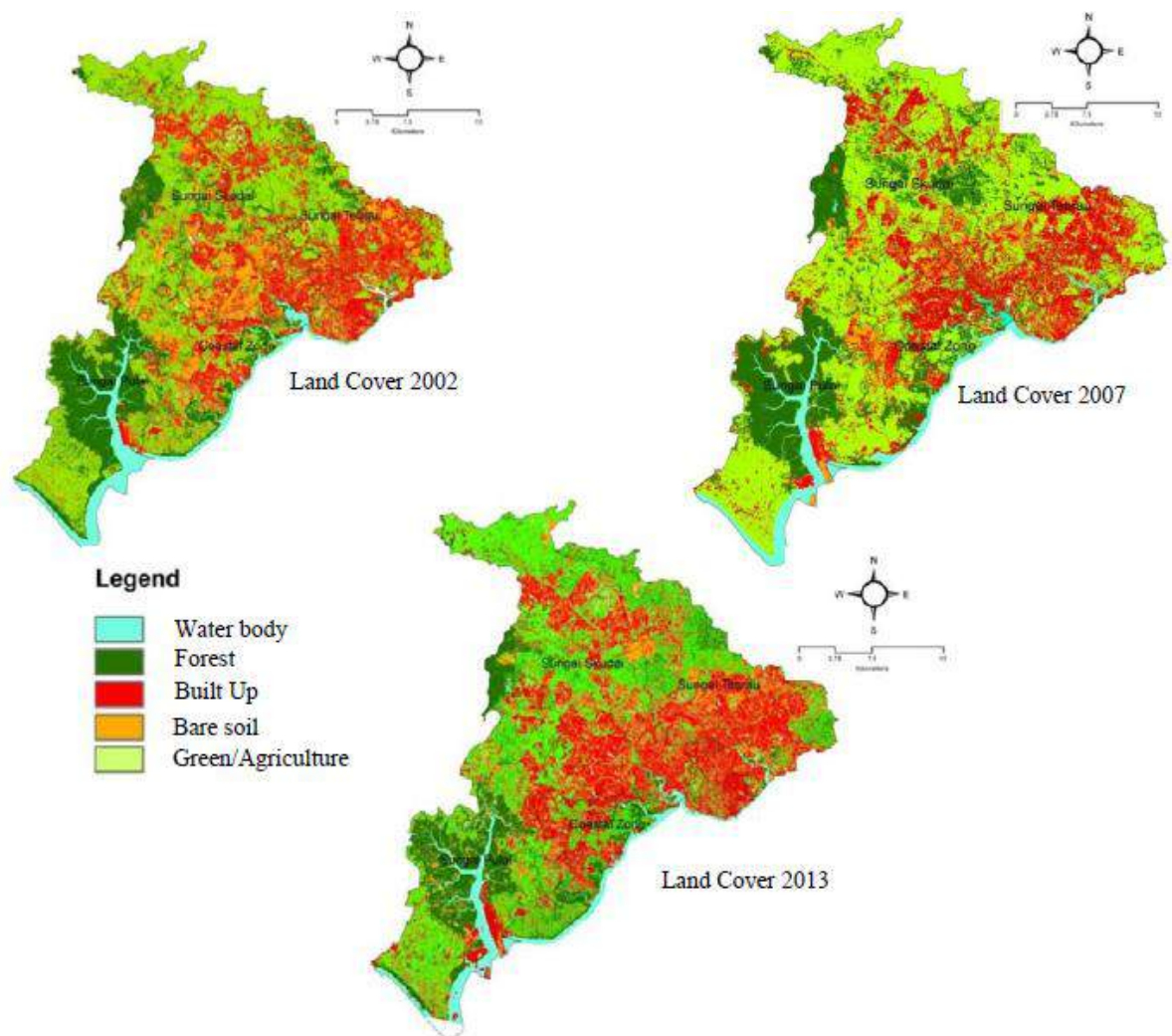

Figure 4: The spatiotemporal dimension of land cover change for the study area from 2002 to 2013 


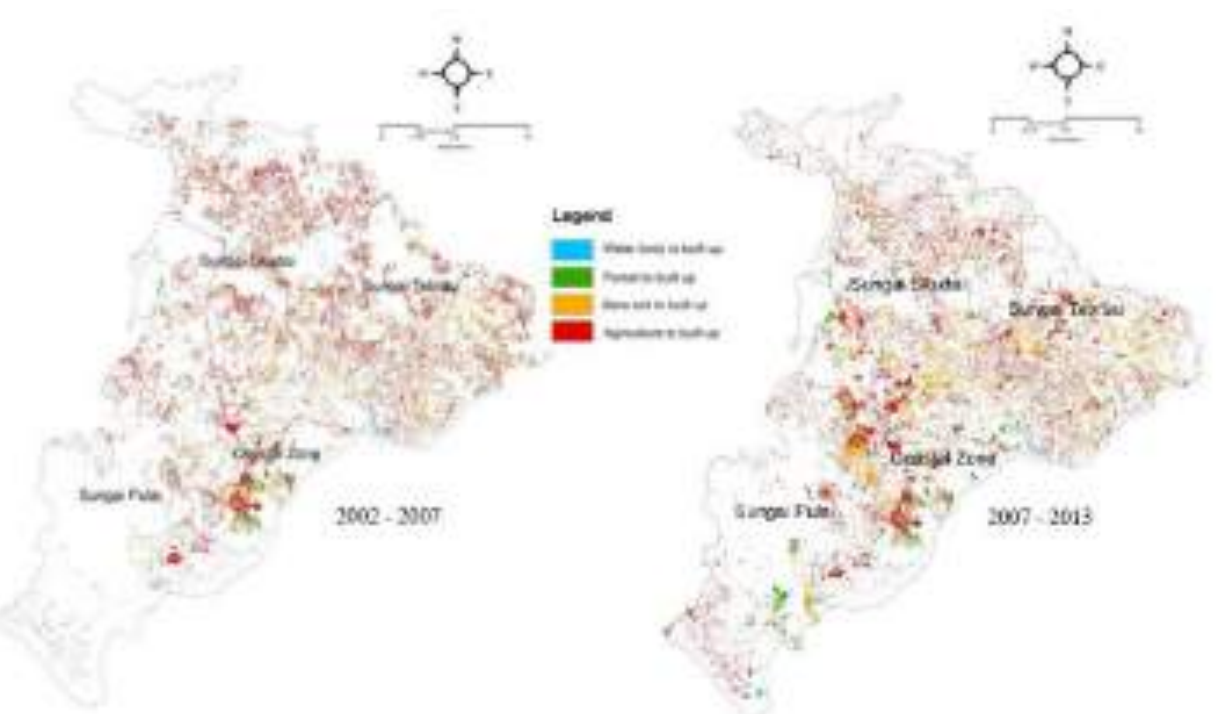

Figure 5: The figure shows the transition of land cover change towards built up areas in all the river basins

Table 3: Transition matrix of the conversion of land cover towards built up areas between 2002-2007 and 2007-2013

\begin{tabular}{|c|c|c|c|c|c|c|c|c|c|c|}
\hline \multirow{3}{*}{$\begin{array}{l}\text { Period } \\
\text { Basin } \\
\text { Land cover } \\
\end{array}$} & \multicolumn{2}{|c|}{ 2002-2007 } & & & & & & & & \\
\hline & \multicolumn{2}{|c|}{ Sg.Tebrau } & \multicolumn{2}{|c|}{ Sg.Skudai } & \multicolumn{2}{|c|}{ Sg.Pulai } & \multicolumn{2}{|c|}{ Coastal } & \multicolumn{2}{|l|}{ Total } \\
\hline & (Hec.) & $\%$ & (Hec.) & $\%$ & (Hec.) & $\%$ & (Hec.) & $\%$ & (Hec.) & $\%$ \\
\hline Water Body & 64.78 & 1.59 & 24.35 & 0.61 & 28.31 & 1.65 & 88.57 & 3.97 & 209.8666 & 1.71 \\
\hline Forest & 330.24 & 8.13 & 377.4 & 9.47 & 273.47 & 15.95 & 458.26 & 20.55 & 1472.9201 & 11.98 \\
\hline Bare Soil & 777.52 & 19.13 & 756.91 & 19.00 & 208.01 & 12.13 & 351.53 & 15.76 & 2144.2356 & 17.44 \\
\hline Agriculture & 2890.85 & 71.14 & 2826.28 & 70.94 & 1204.75 & 70.27 & 1331.99 & 59.72 & 8466.2212 & 68.87 \\
\hline Total & 4063.39 & 100.00 & $\begin{array}{l}3984.94 \\
\end{array}$ & 100.02 & 1714.54 & 100.00 & 2230.35 & 100.00 & 12293.244 & 100.00 \\
\hline \multicolumn{11}{|l|}{ Period } \\
\hline Basin & SgTebrau & & SgSkudai & & SgPulai & & Coastal & & Total & \\
\hline $\begin{array}{l}\text { Land } \\
\text { Cover } \\
\text { Water }\end{array}$ & (Hec.) & $\%$ & (Hec.) & $\%$ & (Hec.) & $\%$ & (Hec.) & $\%$ & (Hec.) & $\%$ \\
\hline Body & 61.65 & 1.57 & 57.46 & 1.19 & 127.22 & 3.54 & 105.88 & 5.39 & 352.21 & 2.46 \\
\hline Forest & 242.79 & 6.18 & 555.18 & 11.53 & 633.13 & 17.62 & 552.36 & 28.13 & 1983.46 & 13.87 \\
\hline Bare Soil & 1155.17 & 29.40 & 1259.69 & 26.17 & 846.87 & 23.57 & 316.75 & 16.13 & 3578.48 & 25.03 \\
\hline Agriculture & 2468.92 & 62.85 & 2941.67 & 61.11 & 1986.25 & 55.27 & 988.45 & 50.34 & 8385.29 & 58.64 \\
\hline Total & 3928.53 & 100.00 & 4814.00 & 100.00 & 3593.47 & 100.00 & 1963.44 & 100.00 & 14299.44 & 100.00 \\
\hline
\end{tabular}


Wan Yusryzal Wan Ibrahim \& Ahmad Nazri Muhamad Ludin

Spatiotemporal Land Use And Land Cover Change In Major River Basins In Comprehensive Development Area

Meanwhile, the Sg. Skudai river basin shows the total conversion area towards urban land is 3984.94 hectares between 2002 and 2007 (Table 3). Similarly agriculture land was the largest area converted into urban land with 2826.28 hectares. The Pulai river basin and coastal zone areas also have significant changes in their existing land cover. Critically, the conversion in the first period in both basins shows that the water body area has been converted extensively. The reclamations of land for urban development along the coastal areas show the replacement of urban land with total 88.57 hectares between 2002 and 2007. Then the enlargement of the transportation hub (Tanjung Pelepas port) shows another significant change of water body to urban land with a total conversion of 28.31 hectare in the Sg. Pulai river basin. As urban development sprawled to the outskirt of Johor Bahru city centre and the demand for urban land use increased, showing the conversion of water body in Tebrau river basin and Skudai river basin with 64.78 and 24.35 hectares respectively. The change of the water body was mostly related to the development of housing area in the river banks directly attached to the rivers. This development trend basically involved the preferences of people want attaching to the serenity of the natural ecosystem.

In the following periods (2007-2013), the total area converted to urban land was 17450 hectares. Similarly agriculture land was the largest area converted to urban land at $60 \%$ of the total conversion. However, the Sg. Skudai river basin saw the largest area converted to urban land with 4818.00 hectares of new development expanded towards Senai and Kulai along both sides of Skudai river. The direction of urban development has changed due to more spaces available in this area as well as in response to increase socioeconomic activities in this direction. The conversion is parallel to the policy stated for the district to enlarge the industrial zone in Johor Bahru district and promoting other land uses such residential and utilities largely developed to fulfill the rapid population growth. More agriculture areas declined with the distribution of development expanding the existing development area. This situation converted all the previous surfaces along the riverbanks to different kind of land use activities. The development processes has removed vegetation from the earth surface and abandoned open soil for a period of time.

Based on the current rapid development, the study has projected the future LULC change in the study area. The implementation of the comprehensive development in this region shows a significant change of urban land in all river basins (Figure 6). It indicates the enlargement of urban footprint replaces other land cover. Urban expansion in 2020, 2025 and 2030 will remove the green areas especially those adjacent to the existing urban boundary (Figure 7). Sungai Pulai and Sungai Skudai river basins having major transformation of land cover change they will receive significant impact spill of development from Johor Bahru city center. Between 2013 and 2020 there will a sharp increase of urban land in Sg. Pulai river basin from $24 \%$ to $35 \%$ and becomes dominant in 2030 with $44 \%$ coverage. On the other hand, vegetation areas will significantly decline in all river basins. Then, starting from 2020 onwards, built up areas become a major land cover in all river basins whereas the vegetation area will be reduced significantly in the future. 

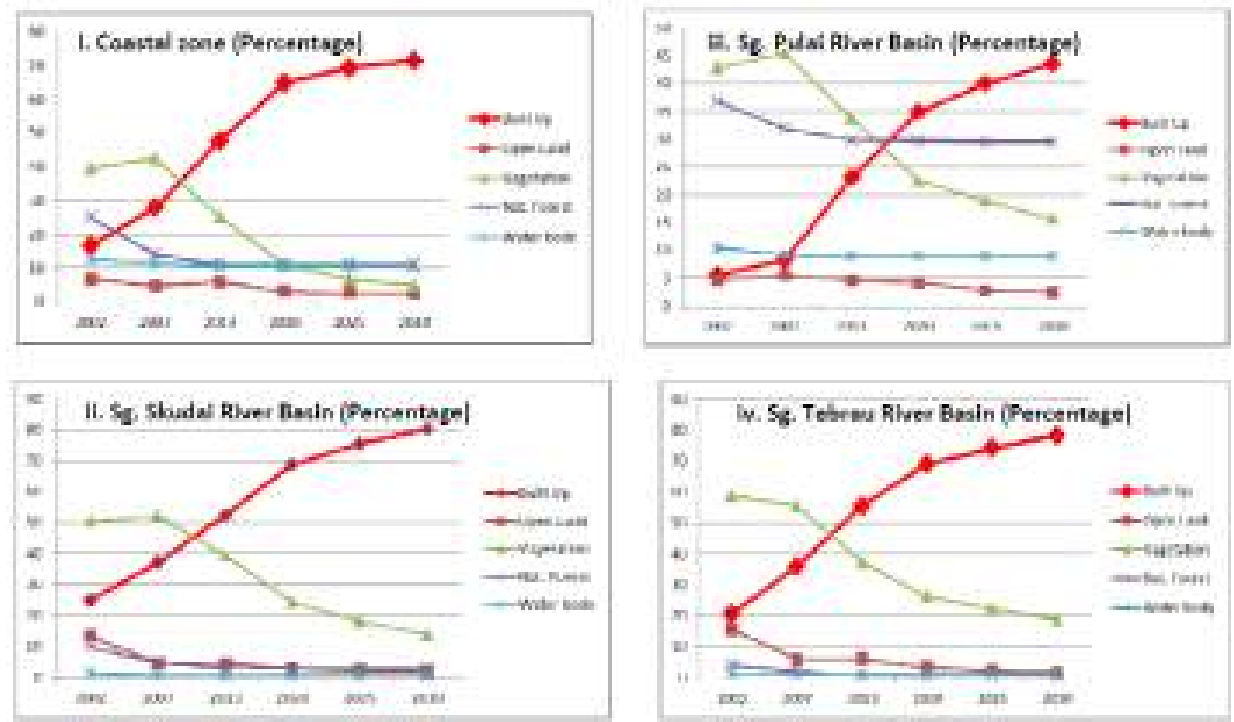

Figure 6: Percentage of landscape (PLAND) change in different river basin in Iskandar Malaysia.

In addition, it can be seen that the trend of future urban development is higher than past periods particularly in Sg. Pulai river basin and also significant compared to past trend (Figure 6 and Figure 7). As a consequence, the area within Sg Pulai river basin shows large agriculture area reducing for artificial development as stated in the development policy. This area will receive the expansion of development from Johor Bahru city centre besides the enlargement of Nusajaya development which merges the urban patches within the basin. The changes also include the expansion of residential and industrial lands in this region within all the river basins. On another perspective, all these land use activities could contribute to significant impact on some environmental issues. 

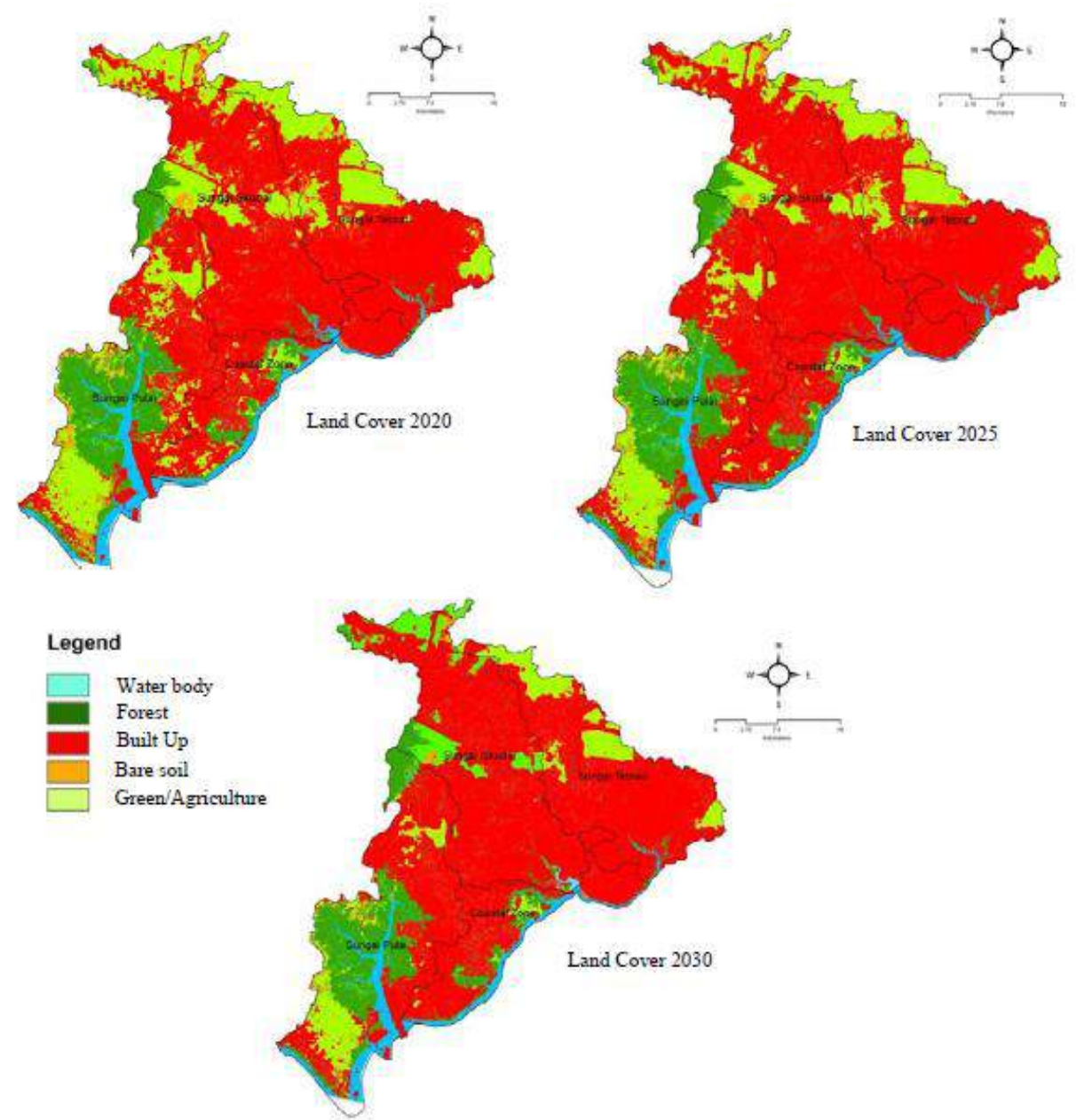

Figure 7: Spatiotemporal dimension of future land use and land cover change in the study area

The implication of the spatiotemporal changed contribute to the enlargement of urban footprint and starting to be dominant in the study area in the future. This concentration of urban development trend causes a huge degradation of other land covers such as agriculture land and natural areas. It changed the earth surface of the region which contributed to high disclosure towards environmental issues such as heat island, flash flood and pollution. Particularly in the river basins, the cumulative impact of large artificial surface would consequently increase the water run-off and non-point source pollution from land use activities. Besides that, as development progressed the large number of bare soil exposed for erosion contributing to the sedimentation of the rivers. This is a critical stage for many rivers in the study area which disturbed their aquatic ecosystems. Thus the landscape configuration and composition with the urbanization are important elements that influence the environmental condition in this study area. 


\section{Landscape configuration and composition characteristic}

The spatiotemporal landscape changes significant transformation on the landscape composition and configuration in the past as well as in future development. In this study, urban landscape configuration and composition are evaluated to show the characteristics of spatial urban pattern changes in the study area with regard to development policy and environmental consequences. From past experience, the changes have restructured the landscape characteristic besides hugely removing green areas (natural and agriculture land). All development within 2002 and 2007 seems to enlarge the existing urban areas and show a small number of patches increased (Figure 8). It can be seen that the developments were allocated in the new areas as the number of patches (NP) increased in all river basin except for $\mathrm{Sg}$. Skudai river basin. The percentage of urban land increased and NP reduced that shows the development has merged the urban patches through infill development. This situation is clear in Sg. Skudai river basin where past rapid development concentrated at the area surrounding Johor Bahru towards Pasir Gudang area where NP decreased from 2398 in 2002 to 1839 in 2013.

The trend was different in the following period where NP slowly decreased in 2013 in all areas except for Sg. Pulai river basin. The urban areas started to merge by removing other areas as percentage of urban area increased. However, the development in Sg. Pulai river basin with also outlying new patches indicates significant change in urban land distribution pattern between 2007 and 2013. The developments were big in this area particularly Nusajaya development and reflects to the concentration scattered development in this area. Overall, the expansion of urban landscape and pattern of development were complying with the development policy.

Future land projection shows that the agglomeration of the urban land constantly expanding their boundary and merging the urban patches. As a result, the NP will decrease tremendously in 2020 and then slowly reduce to 2025 and 2030 levels in all river basins (Figure 8). Overall pattern indicates that the urban land will enlarge their patches in the future and becomes major landscape in all river basins. The expansion will cross the boundary of watershed areas as well as their environmental impact.

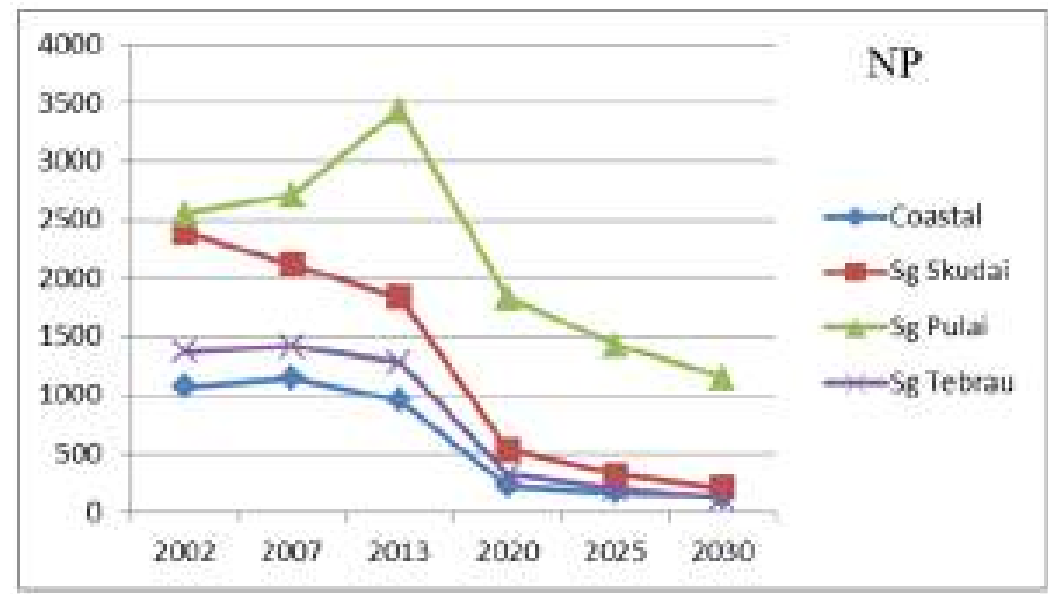

Figure 8: Number of patches for urban land changes 
Wan Yusryzal Wan Ibrahim \& Ahmad Nazri Muhamad Ludin

Spatiotemporal Land Use And Land Cover Change In Major River Basins In Comprehensive Development Area

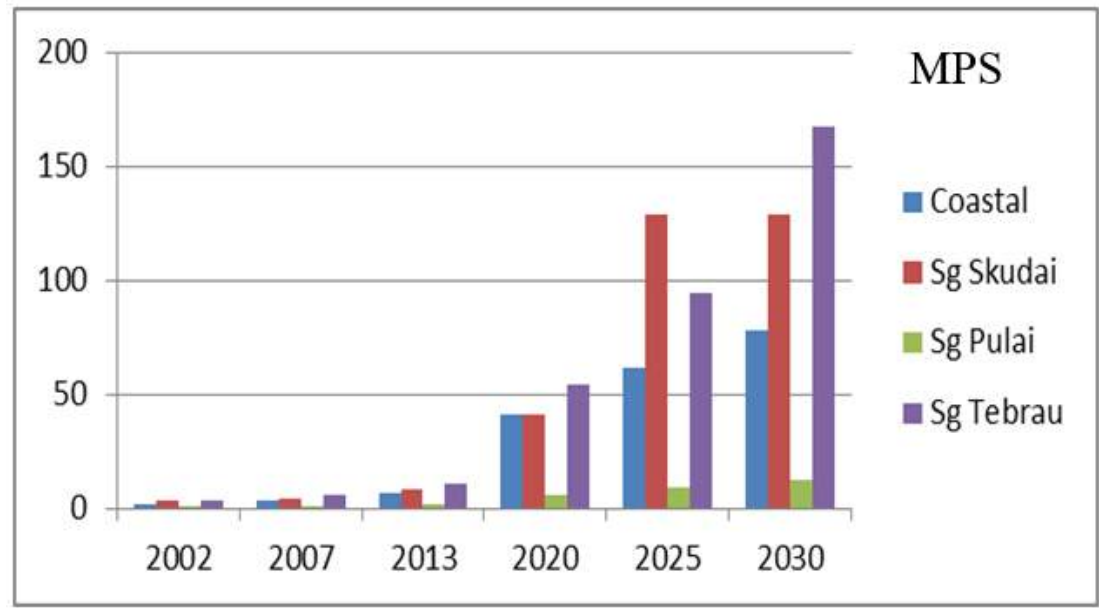

Figure 9: Mean patches size of urban land changes (hectare)

In relation to the spatiotemporal dimension of the study area, the increase of percentage and agglomeration of urban land point out the increase of mean patch size urban area (MPS). Overall development in the past shows the increase of urban patch size to be more significant in the future development in all river basins (Figure 9) were all urban area will merge and the NP will decrease. Nevertheless, the mean patch size of urban land in Sg. Tebrau and Sg. Skudai river basins shows substantial changes in the future. The changes will significantly change the spatial character in the entire landscape and consequently influence the environmental condition of the river basins. The increasing urban land with high concentration of development will change the microclimate and alter the hydrology system particularly water run-off in the river basins. It could contribute to heat island and flash flood when impervious surface increase besides pollution of the rivers. Those issues will be critical when urban land expand their boundary without concern to environmental impacts.

At landscape level, the diversity (SHDI) and evenness (SHEI) of overall landscape are important to evaluate the composition of the entire landscape in the study area. It is related to the distribution of different types of earth surface that influence the environmental condition of the study area. It is seen that the overall spatiotemporal landscape changes in the river basins show the diversity and evenness of landscape is decreasing over past periods and the future. However the diversity of land covers in $\mathrm{Sg}$. Pulai and Coastal zone increased between 2002 and 2013 because it was a huge urban development that changed the existing landscape in this area (Figure 10). The changes also increased the evenness index and indicate that urban land has been distributed with equal complexity in those river basins (Figure 11). On the other hand, the developments contributed to the fragmentation of agriculture and natural land especially the wetland areas along the coastal zone. The concentration of development along the coastal area significantly changed the mangroves areas which has rich ecological value and services. 


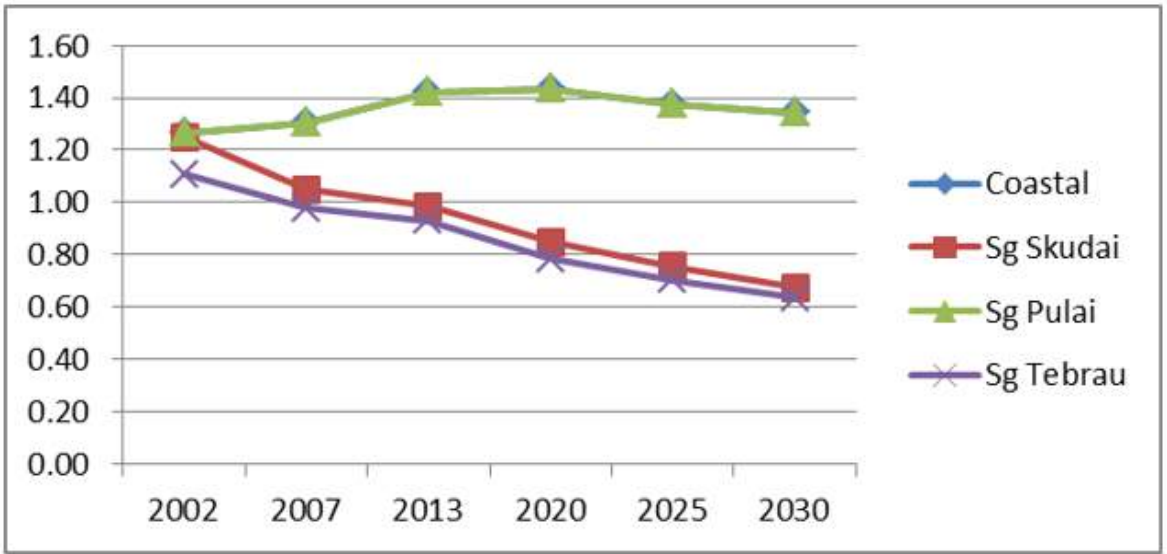

Figure 10: Diversity index (SHDI) of land cover in the river basins

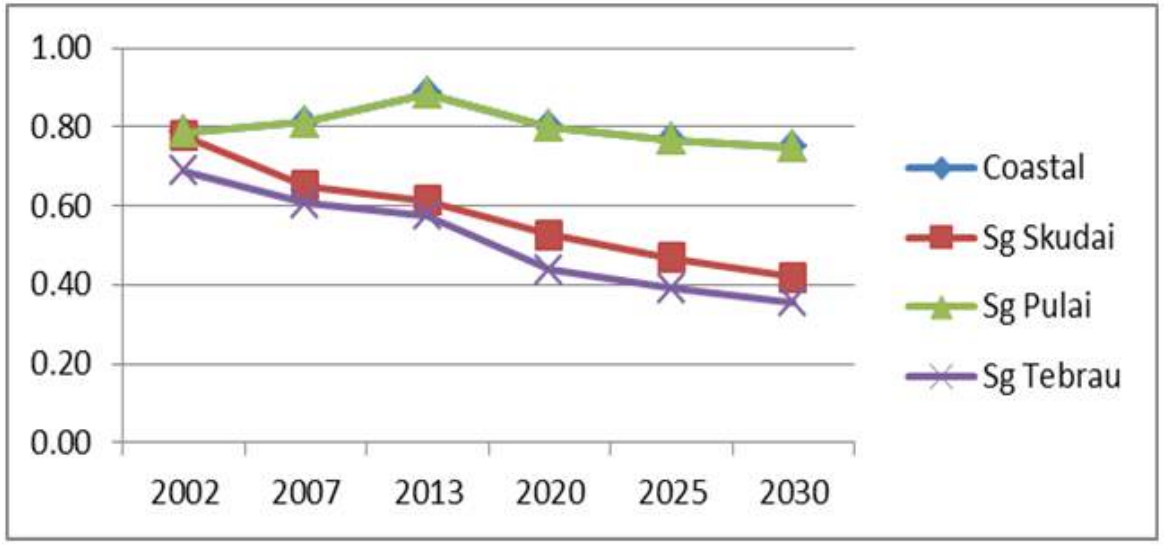

Figure 11: Evenness index (SHEI) of land cover in the river basins

Future changes show a declination of both indexes in all the river basins. This indicates that urban land will expand its area and remove other land covers and subsequently reduce the diversity and complexity of the other land covers. Overall the SHDI index shows the diversity of the land cover for all river basins almost in a similar pattern (Figure 10). However the diversity of the land cover is very significant in the coastal zone compared to the other river basins. It shows the composition of land cover component within coastal zone is diverse and its distribution is even compared to other areas. Meanwhile urban development in Sg. Tebrau and Sg. Skudai river basins hugely influence the diversity and evenness since the urban land cover significantly reduce the complexity of the spatial character in these areas. The implication for the diversity and evenness of the landscape condition reflects particularly on the environmental challenge of the river basins. 
Wan Yusryzal Wan Ibrahim \& Ahmad Nazri Muhamad Ludin

Spatiotemporal Land Use And Land Cover Change In Major River Basins In Comprehensive Development Area

\section{CONCLUSION}

As a conclusion, the study has revealed the overall changes of the spatiotemporal LULC change and its character due to urbanization process. It observed significant changes of the spatial pattern over past periods and in the future. The measurement of the landscape pattern in different basins shows the implication of urbanization towards impacts on the environmental condition. The pressure on the environmental condition is very significant in all river basins and consequently could disturb the community within those areas. In a technical perspective, the integration of GIS and remote sensing in this study has contributed to the understanding of landscape pattern in those river basins. Detail characteristics of land cover give a clear indication on measuring spatial characteristic of landscape changes. Series of satellite images show the important temporal characteristics of LULC changes which can be related to policy evolution and environmental condition.

The spatiotemporal study is beneficial for decision-makers to evaluate the tradeoff in their decision regarding spatial changes. This application allows decision-makers to predict future landscape configuration and composition in relation to environmental condition. Furthermore, the allocation of future land use should be evaluated thoroughly by considering all aspects and consequences. Such elements are crucial to maintain the quality of the entire landscape and conserving the environmental system in the region. This approach could improve management in land use planning and increase the capability of adaptive management.

\section{ACKNOWLEDGMENT}

The authors would like to thank Agency Of Remote Sensing, Malaysia, for providing satellite images in the study area. We also like to thank Department of Town and Country Planning Johor for providing information on development policy and geophysical data.

\section{REFERENCES}

Chu, M. L., Knouft, J.H., Ghulam, A., Guzman, J. A. and Pan, Z. (2013). Impacts of urbanization on river flow frequency: A controlled experimental modeling-based evaluation approach. Journal of Hydrology, 495, 1-12.

Du, J., Qian, L., Rui, H., Zuo, T., Zheng, D., Xu, Y. and Xu, C. (2012). Assessing the effects of urbanization on annual runoff and flood events using an integrated hydrological modeling system for Qinhuai River basin, China. Journal of Hydrology 464-465, 127-139.

Duh, J., Shandas, V., Chang, H. and George, L. A (2008). Rates of urbanisation and the resiliency of air and water quality. Science of the Total Environment, 400, 238 256.

Edwin D. Ongley, E. D., Xiaolan, Z. and Tao, Y (2010). Current status of agricultural and rural non-point source pollution assessment in China. Environmental Pollution, $158,1159-1168$.

Fan and Myint (2014). A comparison of spatial autocorrelation indices and landscape metrics in measuring urban landscape fragmentation. Landscape and Urban Planning, 12, 117-128.

Frondoni, R., Mollo, B. and Capotorti, G. (2011). A landscape analysis of land cover change in the Municipality of Rome ( Italy ): Spatio-temporal characteristics and 
ecological implications of land cover transitions from 1954 to 2001. Landscape and Urban Planning, 100(1-2), 117-128.

Fu, Y., Ruan,B., Ge, H. and Zhao, N. (2014). Agricultural non-point source pollution in the Yongding River Basin Wenxian Guo. Ecological Indicators 36, 254- 261.

Jiang, J., Li, S., Hu, J., Huang, J. (2014). A modeling approach to evaluating the impacts of policy-induced land management practices on non-point source pollution: A casestudy of the Liuxi River watershed, China. Agricultural Water Management $131,1-16$.

Jiayu Wu, J. and Jan Thompson, J. (2013).Quantifying impervious surface changes using time series planimetric data from 1940 to 2011 in four central Iowa cities, U.S.A. Landscape and Urban Planning 120, 34- 47.

Lathrop, R. G., Tulloch, D. L. and Hatfield, C. (2007). Consequences of land use change in the New York-New Jersey Highlands, USA: Landscape indicators of forest and watershed integrity. Landscape and Urban Planning 79, 150-159.

Mark A. Carlson, M. A., Lohse, K. A., McIntosh, J. C. and McLain, J. E.T (2011). Impacts of urbanization on groundwater quality and recharge in a semi-arid alluvial basin. Journal of Hydrology 409 (2011) 196-211.

McGarigal, K., Cushman, S. A., Neel, M. C., E., 2002. Fragstats: spatial pattern analysis program for categorical maps. www.umass.edu/landeco/research/fragstats/fragstats/html.

Rose, S. (2007). The effects of urbanization on the hydrochemistry of base flow within the Chattahoochee River Basin (Georgia, USA). Journal of Hydrology, 341, 4254.

Schaffner, M., Hans-Peter Bader, H. P. and Scheidegger, R. (2009). Modeling the contribution of point sources and non-point sources to Thachin River water pollution. Science of the Total Environment, 407, 4902-4915.

Shena, Z., Houa, X., Wen Li, W. and Guzhanuer Aini, G. (2014). Relating landscape characteristics to non-point source pollution in a typical urbanized watershed in the municipality of Beijing. Landscape and Urban Planning, 123, 96- 107.

Sun, X., He, J., Shi, Y., Zhu, X. and Li, Y. (2012). Spatiotemporal change in land use patterns of coupled human-environment system with an integrated monitoring approach: A case study of Lianyungang, China. Ecological Complexity 12, 23-33.

Tanga, Z., B.A. Engela, B. A., Pijanowskib, B.C., Lim, K.J. (2005). Forecasting land use change and its environmental impact at a watershed scale. Journal of Environmental Management 76, 35-45.

United Nation. Population Division of the Department of Economic and Social Affairs of the United Nations Secretariat, 2009. World Population Prospects: The 2008 Revision and World Urbanization Prospects: The 2009 Revision. Available at http://esa.un.org/unpd/wup/Maps/maps_1_2025.html.

Wang, X., Wang, Q.,Wu, C., Liang, T., Zheng, D., Wei, X. (2012). A method coupled with remote sensing data to evaluate non-point source pollution in the Xin'anjiang catchment of China. Science of the Total Environment, 430, 132-143.

Xiana, G., Craneb, M., Suc, J. (2007). An analysis of urban development and its environmental impact on the Tampa Bay watershed. Journal of Environmental Management 85, 965-976. 
Wan Yusryzal Wan Ibrahim \& Ahmad Nazri Muhamad Ludin

Spatiotemporal Land Use And Land Cover Change In Major River Basins In Comprehensive Development Area

Xu, X. and Min, X. (2013). Quantifying spatiotemporal patterns of urban expansion in China using remote sensing data. Cities, 35, 104-113.

Youa, Y.Y., Jina, W.B., Xionga, Q.X., Xueb, L., Aib, T.C. and Lia, B.L. (2012). Simulation and Validation of Non-point Source Nitrogen and Phosphorus Loads under Different Land Uses in Sihu Basin, Hubei Province, China. Procedia Environmental Sciences, 13, 1781 - 1797 .

Zhang, H. and Huang, G. H. (2011). Assessment of non-point source pollution using a spatial multicriteria analysis approach. Ecological Modelling, 222, 313-321.

Zhang, P., Liu, Y., Pan, Y. and Yu, Z. (2013). Land use pattern optimization based on CLUE-S and SWAT models for agricultural non-point source pollution control. Mathematical and Computer Modelling, 58, 588-595 